\title{
Correction to: The protein kinase $C \beta$-selective inhibitor, enzastaurin, attenuates amphetamine-stimulated locomotor activity and self-administration behaviors in rats
}

Rachel D. Altshuler ${ }^{1} \cdot$ Colleen A. Carpenter ${ }^{1} \cdot$ Timothy J. Franke $^{1} \cdot$ Margaret E. Gnegy $^{1} \cdot$ Emily M. Jutkiewicz $^{1}$

Published online: 3 July 2019

(C) Springer-Verlag GmbH Germany, part of Springer Nature 2019

\section{Correction to: Psychopharmacology}

https://doi.org/10.1007/s00213-019-05278-0

The middle initial of the author should be "A" instead of " $\mathrm{C}$ ". The correct presentation of the author name is Colleen A. Carpenter.

The original article has been corrected.

Publisher's note Springer Nature remains neutral with regard to jurisdictional claims in published maps and institutional affiliations.

The online version of the original article can be found at https://doi.org/ 10.1007/s00213-019-05278-0

Emily M. Jutkiewicz

ejutkiew@umich.edu

1 Department of Pharmacology, University of Michigan, $1150 \mathrm{~W}$.

Medical Center Dr, Ann Arbor, MI 48109, USA 